\title{
Life Skill Education Model through Integrated Learning Approach
}

\author{
N. Rohaeni, Supandi, M. P. Ningsih \\ Department of Home Economic Education \\ Faculty of Technical and Vocational Education \\ Universitas Pendidikan Indonesia \\ Bandung, Indonesia \\ nrohaenisy@gmail.com
}

\begin{abstract}
- this research is conducted by the fact that the attention for developing the life skill education in formal, nonformal and informal is still inadequate. According to such evidence, this research aims to develop life skills education model through integrated learning approach in improving learners specialization. The development of this model is conducted by using the Research and Development approach, through certain stages, such as: (1) Preliminary study, (2) Developing the model, and (3) Validating the model. Firstly, the stage of preliminary studies covers several activities, such as: (a) The literature study which related to the investigated problem, (b) Identification the characteristics of life skills education that are integrated in the specialization program based on the experts and practitioners opinions, (c) Description of learning implementation on program specialization, (d) Designing life skills education model through integrated learning approach in improving learners specialization. Second, the development stage covers several activities, such as: (a) Development of life skills education teaching materials, (b) Testing the trial model until it is ready for validation. At the last stage, it consisted of several activities, such as: (a) Validation of the model through empirical studies, (b) Evaluation and improvement of the model to produce a model final. In accordance to the stages of research that have been stated above, this study is aimed to have the following outcomes: (1) Model of life skill education with integrated learning approach to improve learners specialization, and (2) life skills education teaching materials.
\end{abstract}

Keywords-Model, life skills education, Integrated Learning, Specialization, Learners

\section{INTRODUCTION}

Education is an important factor in developing Human Resources (HR) quality. Education can be implemented through formal education which organized in schools, nonformal education which held in communities, and informal education which is carried out within the family.

Life skill education is more oriented to the values of education, which is currently developed on the constructions of character building. Education seeks to instill how to live according to the teachings of religion, cultural demands, social and personal development, in addition to train some household or vocational works. The contents of life skill education are very important to develop the character building which is charged by the government through various methods in teaching and learning process at schools.

Life skill education as a catalyst in developing a character building needs to be implemented at early stages, which can be initiated in elementary education, by the consideration of the nine-years compulsory education. In addition, Depdiknas (2002) suggests that elementary education aimed to providing basic skills provision for learners to develop their lives as individuals, community members, citizens and members of the human race and also to prepare them to attend higher education.

A phenomenon that occurs at the moment is that the life skill education received less attention, especially in formal education which held at the school, since the removal of the Family Welfare Education (PKK) subjects in the structure of the school curriculum in 1994. Therefore, life skills education model should be designed and implemented that is integrated in the curriculum implementation at the school. One of many efforts that can be realized is through the implementation of integrated learning in the local curriculum in junior high, because there are still some schools that develop household skills and tourism courses. The research findings that were paraphrased from Nurlaela (2006) such as, the implementation of integrated learning model has provided enough the opportunities for involvement of learners' various experiences. It is because of the learning themes could be selected from the things which proposed by learners. Teachers develop learning activities that refers to the multiple intelligences because it provides choices, organize students into small groups (collaboration), and provide opportunities for learners to produce real products to the real goals (mastery/application level). The conclusions derived from the research which conducted by Nurmawati (2008) dealt with the application of webbed model, namely: (1) Application of integrated learning through webbed model can be implemented properly in order to teach learners about the themes of family; (2) The use of the model webbed in integrated learning can improve comprehension of the mathematic, science, Indonesian and SBK competencies through family themes in the second grade students at SDN Gondowangi III. (3) The impact of the webbed model in integrated learning can improve students' activity, cooperation, courage and a sense of joyfulness students in learning. 
Household Skills and Tourism programs provided to support the realization of the national education goals with emphasizing on the appreciation of the learners works as a basis for the establishment of work ethic and some provisions for learners in the aspect of knowledge, basic skills and ability to develop their character and to contribute to the local development. Therefore, the learning that can provide a comprehensive learning experiences very much needed, especially with regard to knowledge, attitudes and skills in accordance with the task of development. This kind of learning will be successful if the teacher, as an actor in learning competence and professional, is able to design, implement and evaluate learning activities. In line with the statement that proposed by Cooper (1990), he stated that, in common, there are four areas of competence that must be possessed by teachers to design and organize the effective learning activities. These four areas are as follow: 1) Comprehending the theory of learning and human behavior, 2) Displaying the attitudes to encourage learning process, and understanding human relationships, 3) Understanding the subject matters that is to be taught to students, and 4) Controlling the ability of teaching techniques that can facilitate the students learning activities. Such competencies demands indicate that the teacher is the central component that holds a role in determining the quality of learning that will have implications in the development of human resources. Thus a person who has a profession as teachers is required to have competencies that describe those specific qualifications or abilities.

From the various phenomena which mentioned above, it is necessary to conduct the research on the development of life skills education model through integrated learning approach in improving learners specialization.

\section{RESEARCH METHOD}

This study was conducted through the Research and Development $(\mathrm{R} \& \mathrm{D})$ approach that will be implemented in three stages, namely: (1) Preliminary Study, (2) Model Development and (3) Validation Model in accordance with the problems and objectives that have been formulated before.

The study was conducted on the implementation of the learning of local content courses in junior high school, with the subject of the study consisted of students and teachers which involved in local content courses.

Collection and analysis the data of research are classified into three stages, namely:

\section{Preliminary Study}

In the implementation of the pilot study, the researcher used interview, observation and study documentation and also supported by literature review in order to generate the design of Life Skill Education model through integrated learning approach in improving learner's specialization. The findings of the Life skills Education model through integrated learning approach in improving learner's specialization have been described in narrative form of data presentation, and then analyzed qualitatively.

\section{Model Development}

At this stage, researcher's tested the design of Life skills Education model through integrated learning approach in improving learner's specialization until generating fixed model that is ready for validation. The development phase consists of several approaches in analyzing the data of research findings, namely: 1) Implementation and results of developing the model of Life Skill Education through integrated learning approach in improving learners specialization have been presented in the form of narrative description, which is then analyzed qualitatively. 2) At the trial of the model of Life Skill Education through integrated learning approach in improving learners specialization, the results of trial implementation of designed model was analyzed with quantitative approach.

3. Validation Model

At this validation stage, expert judgments were conducted in order to generate a valid model of Life Skill Education through integrated learning approach in improving learners specialization. Significance of the result in applying the model as validation testing through expert judgments were analyzed using a qualitative approach.

\section{RESULT AND DISCUSSION}

\section{A. Description Preliminary Study}

SMP Negeri 3 Lembang is one of schools which organizes specific skills program, such as program of agricultural skills, crafts and household. Household skills courses which were held at the level of junior high school (SMP) is one of the attempts to provide basic skills for students who may be developed in accordance with their own capabilities. The objectives of household skills program at SMP level has been listed in GBPP Skills Program, namely:

a. To enhance the work appreciation of learners as a basis for development of a work ethic.

b. To provide and support learners with the basic working skills in accordance with the stage of development of middle age children.

In the household skills programs, the learners will study several certain skills, such as dressmaking skills, catering and management of household, in which these program are expected to improve specialization for learners. The course objectives of household skills as listed in GBPP household skills programs, namely: to provide knowledge and skills for graduated learners in catering and dressmaking skills, to be able to develop the attitudes and skills that acquired to participate in local development, especially in the tourism area and continuing study on secondary education. 
Household skills program has changed and adjusted since the implementation of Curriculum 2013 with the subject name as craft course. A craft is one of the new subjects in the 2013 secondary curriculum. This course is held as the impact of the abolition of the subjects of ICT, PLKJ and local courses (i.e. Catering, dressmaking and Commerce Services). Craft course is an integration of 4 subjects above and were merged into one and named craft course.

Craft course consists of four aspects, namely handicraft, processing, cultivation, and engineering. Schools are subjected to choose at least two aspects that are tailored to the capabilities and availability of the local area.

1) Crafts

Craft means the form of crafts using natural materials that are all around us, for example making handicrafts made of clay and ceramics.

2) Processing

The actual processing is subject catering. This aspect may be the choice for teacher at the school as it is intended for making and processing of food and beverages.

3) Cultivation

Cultivation is suitable in the urban area and adapted to the surrounding environment, for example fish and chicken breeding, or farming.

4) Engineering

Engineering is a subject relating to electro, for example, stringing an electrical circuit or collating a bell.

Craft learning is developed by the peculiarities of the local area along with an understanding of culture creation background and application of appropriate technology. Through craft learning, it will give appreciation to the students about the meaning of multicultural. Craft learning course is included in the constellation of Indonesian Education curriculum as a compulsory subject, which is in general, it is expected to contribute in developing the creativity of human resources at "creative economy industry" that is being promoted in the educational discourse of "national character".

Life Skill Education Program which was held in SMP Negeri 3 Lembang in the form of integrated Household skills programs are including various subjects such as Fashion Design, Gastronomy and Household Management.

The research findings in the relations to the Life Skill Model Education through Integrated Learning approach for improving Students' specialization, are including character education such as follows: 1) Honesty, 2) Accuracy, 3) Independence, 4) Precautionary, 5) Accuracy, 6) Perseverance , 7) Dexterity, 8) Creativity.

In accordance with the currently implemented curriculum, namely the curriculum in 2013, the Life Skill education material can be integrated in the Handicraft subject. Character
Education can be accommodated and integrated in the execution of Handicraft subject learning process, so the students could acquire a learning experience which can help develop their potential according to their interest. The development of this model adopts Integrated Learning from Fogarty (Syaodih, 2004; 197-200) such as follows:

1. Fragmented Design, instructional design which is commonly used in the current studies. The topic which contains teaching materials is separated from one another. Likewise, in the implementation of learning process, the discussion will only cover the material on a certain topic.

2. Connected Design, learning in a certain subject or learning materials are designed in a way so they link from one topic to another, one concept to another within same time frame or different.

3. Nested Design, within the same subject matter or field of study, the topic of discussion is directed in such a way to enable students master several abilities or skills, such as thinking skills (intellectual), social skills, motor skills.

4. Sequenced Design, between two or more subject matters or primary subject at the same time which contained similarities or relationship between topics, materials, concepts or skills developed.

5. Shared Design, educator from two or more subject matters is teaching materials, concepts, capabilities that have similarity or relation to one another, and they shared the task of teaching in the form of the team (team teaching).

6. Webbed Design, the learning is focused on one or several themes. Each theme covers several topics, concepts, or problems in a number of subject matters.

7. Threaded Design, Learning is directed to establish thinking skills, social skills, multiple intelligence, technology and skills learned in the various fields of study. For example, thinking skills to see and figure out the relationship of cause-effect.

8. Integrated Design, the process of learning is integrally designed from a variety of subject matter, or subject, summarizes material from a variety of subject matter. This design is also known as an interdisciplinary learning or cross-disciplinary subjects.

9. Immersed Design, the design and implementation of learning are immersing with the students. The subject matter, theme or learning materials is chosen by the students themselves and depending on what subjects they need and enjoy most. This design is also an integrated design, which is not only integrates across 
the subject matter but also integrates between the teaching materials with students themselves.

10. Networked Design, integrated learning design which combines teaching materials or knowledge from a wide range of subject matter and various learning resources network. Students act as an expert, in searching, collecting and selecting needed knowledge.

B. Life skills Education model through integrated learning approach in improving learner's specialization

Increasing student's interest in the learning of Handicraft can be sought through the development of learning materials and learning experiences which are tailored to the demands of the curriculum in 2013 and the needs of students. By accommodating the needs of students will have implications on improving the quality of teaching and learning process and the learning results of students, so they could develop the potential, creativity and attitude as well as fostering the independence to be utilized in the future life. Based on the results of the preliminary study, Life skills Education model through integrated learning approach in improving learners specialization is designed as follows.

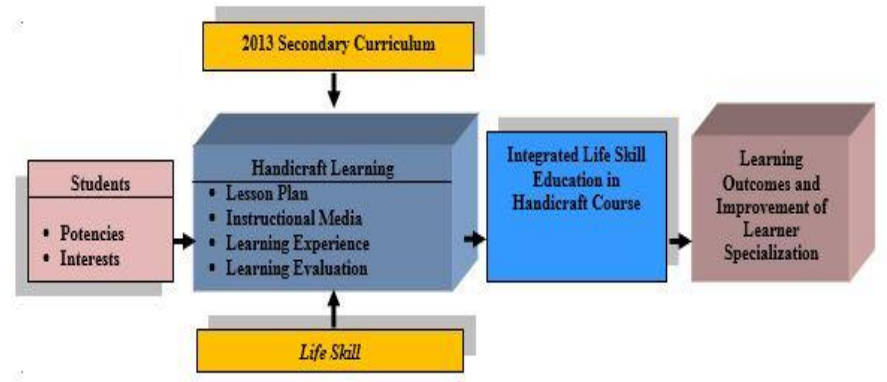

Life Skills Education Model through Integrated Learning Approach In Improving Learners Specialization

\section{CONCLUSION}

From all the research activities can be drawn conclusions as follows:

1. Life Skill Education Program held in Junior High school in the form of Household Skill Programs which integrates to subjects as Fashion Design, Gastronomy and Household Management.

2. Life skills Education model through integrated learning approach in improving learner's specialization is filled with character education that aims to cultivate honesty, thoroughness, independence, carefulness, thoroughness, perseverance, dexterity and creativity.

3. Life skill Education teaching materials are developed by referring to the structure of the education unit curriculum which are being implemented and its characteristics as well as the interest of students.

4. Life skills Education model through integrated learning approach in improving learner's specialization adapts the characteristics and needs of the students in order to help learners to increase the interest in learning the subject of Household Management skills as a compulsory subject in junior high.

5. Life skills Education model through integrated learning approach in improving learners specialization, deserves to be implemented on subjects of Handicraft and Household Management which is filled with Character Education

\section{REFERENCES}

[1] Cooper, James M. (1990). Classroom Teaching Skills.Canada: D.C. Healt and Company.

[2] Mone. (2002). Life skills-oriented education (Life Skills Education). Jakarta.

[3] Nurlaela, L. (2006). Application of Integrated Learning Model (Integrated Learning) Education to Enhance Resilience Understanding Food in SD. Journal Volume 7 No. 1

[4] Nurmawati, L. (2008). Webbed use of models in an integrated learning to improve understanding of various competencies on family themes grade II SDN Gondowangi III Wagir District of Malang. Malang: State University of Malang.

[5] Syaodih, N, (2004), Curriculum and Learning Competency. Bandung: Yayasan Kusuma. 